\title{
Three lessons from Ed Diener
}

\author{
Robert Biswas-Diener • Todd B. Kashdan
}

\section{Introduction}

Dr. Ed Diener, sometimes called "Dr. Happiness" because of his pioneering research on wellbeing, passed away April 27th, 2021, in Salt Lake City, Utah (USA). Diener was well-known as a founder of positive psychology and a pioneer in wellbeing research. His academic career spanned five decades, and he published hundreds of articles and chapters. His work has been cited more than 250,000 times and, combined with his h-index (181), Diener was the 172nd most highly cited scientist in the world, across all disciplines. His Satisfaction with Life Scale alone has been cited over 30,000 times.

Diener was a fellow of the American Academy of Arts and Sciences and a senior scientist at the Gallup Organization. He won the highest awards in psychology, including the Award for Distinguished Scientific Contribution from the American Psychological Association (APA) and the William James Fellow Award from the Association for Psychological Science (APS). He served as president of the International Positive Psychology Association (IPPA), the International Society for Quality of Life Studies (ISQOLS), and the Society for Personality and Social Psychology (SPSP). In the early 1990s, Diener was the editor of the top journal in his field, the Journal of Personality and Social Psychology. He was also the founding editor of the Journal of Happiness Studies and Perspectives on Psychological Science.

Given his stature in the field, it is fitting that we reflect on the lessons we can take from Diener's research career. Although there are many, we focus on three central lessons:

\section{Lesson one: An emphasis on descriptive science}

Although Diener's research program built on prior scientific discoveries, he was especially inspired by three scientists: 1) Tycho Brahe, the father of modern astronomy, 2) Karl von Frisch, the Nobel-Prize winning ethologist who discovered "the dance of the bees," and 3) Jane Goodall, the primatologist and conservationist who mapped previously unknown chimpanzee behaviors. All three of these researchers share in common an approach to science that emphasized pure observation over theory. They were empiricists in the strictest definition of the word. They did not seek to prove their hunches, nor were they bound by existing theoretical approaches. They were, in essence, curious to observe.

Ed Diener advocated a similar approach to happiness studies. After spending years establishing definitions and valid measures of wellbeing, Diener simply wanted to chart happiness as it exists in the world. He was curious to see who had happiness, how much of it they had, when they had it, and how it varied over time and context. It is hard to highlight just how radical a descriptive approach to science is in the modern age. Research reviewers often criticize submissions for lack of theoretical foundation. Ed, by contrast, believed that it made more sense to collect decades of data before forming theories. This approach is especially 
conspicuous in his publications from the 1990s, in which he investigated levels of happiness as they relate to income (e.g., Diener \& Fujita, 1995; Diener, Sandvik, Seidlitz, \& Diener, 1993), culture (e.g., Oishi, Diener, Lucas, \& Suh, 1999; Suh, Diener, Oishi, \& Triandis, 1998), and other demographic variables (e.g., Gohm, Oishi, Darlington, \& Diener, 1998;). He was not opposed to theory, of course, but did not lead with it.

Even when he addressed theoretical explanations for his research findings, Diener was careful not to rush to closure on any single theory. A noteworthy example of this can be found in his publication discussing societal differences in wellbeing (Diener \& Lucas, 2000). Researchers often observe societal differences in wellbeing, and it is tempting to explain such findings with singular confidence. More typical of his intellectual humility, however, Diener and his colleague suggested many distinct possibilities, including the use of relative comparison standards, the fulfillment of basic needs, and local cultural influences on wellbeing. The researchers suggested the possibility that, when making judgments of life satisfaction, people might make their evaluations on a complex and individualized set of relevant information. As always, when they suggested that more research is needed before accepting this idea, they meant it.

\section{Lesson two: Scientific rigor}

When Diener became the editor of the Journal of Personality and Social Psychology in 1998, he argued for greater scientific rigor. In particular, he advocated for multi-study and multi-method research (Diener, 1998). For example, when investigating cultural variation in emotion, he and his colleagues employed diverse samples and used a variety of measurement strategies, including global wellbeing judgments, experience sampling, and memory measures (Scollon, Diener, Oishi, \& Biswas-Diener, 2004). This research approach was typical of Diener, adopting sophisticated methodologies, as required, to adequately answer the question asked. He often employed larger and more representative samples (such as 136,839 respondents from 132 world countries; Diener, Ng, Harter, \& Arora, 2010), multiple methods simultaneously (such as anticipatory, experience sampling, and retrospective assessments of the same spring break vacation; Wirtz, Kruger, Scollon, \& Diener, 2003), and employed strong research designs such as multi-study replication and randomized controlled trials (e.g., Heintzelman et al., 2020).

Although well-known for his research on happiness, Diener frequently published directly on methodological considerations. These included establishing the discriminant validity of wellbeing measures (Lucas, Diener \& Suh, 1996), discussing effect sizes in happiness research (Geerling \& Diener, 2018), and critically reviewing affect induction procedures (Chan, Heintzelman, Tay \& Diener, 2020). Diener believed that research results are only as good as the science that produces them and remained a champion of tailoring measurement, sampling, and design to the phenomena under investigation.

Long before the "replication crisis" came to popular attention, Diener was concerned with the generalizability and precision of results. For example, he and his colleagues found that "most people are happy" (Diener 1996). This finding set the foundation for later discoveries about the beneficial consequences of happiness (e.g., Lyubomirsky, King \& Diener, 2005). Despite the initial evidence, Diener and his colleagues returned to this finding throughout his career as better data emerged. They did so in the hopes of adding more nuance to our understanding of the topic. For example, using data from non-traditional samples of the Maasai in Kenya, Inughuit people in Greenland, and Amish communities, he and his colleagues noted cultural variation in the "most people are happy" conclusion (Biswas-Diener, Vittersø \& Diener, 2005). Then, in 2018, Diener and his colleagues revisited decade-old findings with survey data from 1,551,362 respondents from 166 countries (the Gallup World poll; Diener, Diener, Choi \& Oishi, 2018). This 
more representative sample allowed Diener and his colleagues to chart the limits of the "most people are happy" finding, especially for those living in dire circumstances.

\section{Lesson three: Great research questions}

Among the greatest skills in all of research is the ability to form excellent questions to drive investigation. Diener was fond of saying that research was more about asking questions than finding answers. For him, the thrill was chasing ever-expanding knowledge. Evidence for his love of learning can be found in the titles of several publications, where the framing is set around lingering curiosities: Does happiness improve health? Do happy people care about society's problems? Does positivity enhance work performance? Is valuing positive emotion associated with life satisfaction? Can and should happiness be a policy goal? The list goes on. These are the questions that interest laypeople and the rest of society, not just academic researchers. It is for this reason that hundreds of media outlets regularly reported on his work (such as "What Makes Us Happy" in the June 2009 issue of The Atlantic and "Exploring Life at the Top of the Happiness Scale" in the January 29, 2002 issue of The New York Times).

It is noteworthy that Diener rarely investigated small questions such as specific moderating or mediating relationships between variables. Certainly, he mentioned such relationships in the course of his analyses, but these were rarely the primary focus of his research. Instead, he focused on larger questions. He was curious about broad topics and knew that it would take multiple studies to explore the issues of stability, directionality, and causality. For instance, Diener spent decades investigating the multi-faceted relationship between income and happiness. He believed the question "does money buy happiness?" could be answered but that it was difficult to do so. Across his career, Diener explored the happiness of the very wealthy (Diener, Horowitz \& Larsen, 1985), of the very poor (Biswas-Diener \& Diener, 2001), the effect of progressive taxation (Oishi, Shimmack \& Diener, 2012), the effects of rising income (Diener, Tay \& Oishi, 2013), and the effects of living among the wealthy (Tay, Morrison \& Diener, 2014), to name just a few avenues of answering the money-happiness question.

Another hallmark of Diener's inquisitiveness was an appreciation of complexity - and a refusal to accept simple explanations for the human population when a wide range of individual differences and cultural variation exists. Evidence for this can be seen in a tangential research program attending to the psychology of religion. Compared with his publication record on income or culture, he published relatively little on religion. Over the decades, however, he returned to the topic time and again. In this example, he was not satisfied with the simple question of the relative levels of happiness of religious people. Instead, he asked tougher questions. He investigated the question of why people drop out of religion if it is beneficial (Diener, Tay \& Myers, 2011) and the distinctive role of religious belief versus religious behavior (Diener \& Clifton, 2002). Diener's research often belied sound-bite results in favor of nuanced wisdom.

\section{Conclusion}

Dr. Ed Diener was a prolific researcher who serves as an exemplar for those interested in trying to capture why humans do the things they do and where and how we can intervene for the betterment of humanity. His devotion to high-quality research serves as a guide for asking questions, sampling, measuring, and designing studies of wellbeing that are appropriate for the topic under consideration. Deconstructing his contributions, one walks away with a template for how to do great work that improves our understanding of humanity, has real-world relevance, and lasts the test of time. 


\section{Authors}

Robert Biswas-Diener

Positive Acorn

Robert@PositiveAcorn.com

Todd B. Kashdan

George Mason University

\section{Publishing Timeline}

Received 2 May 2021

Accepted 2 May 2021

Published 31 May 2021

\section{References}

Biswas-Diener, R., \& Diener, E. (2001). Making the best of a bad situation: Satisfaction in the slums of Calcutta. Social Indicators Research, 55(3), 329-352. https://doi.org/10.1023/A:1010905029386

Biswas-Diener, R., \& Diener, E. (2006). The subjective well-being of the homeless, and lessons for happiness. Social Indicators Research, 76(2), 185-205. https://doi.org/10.1007/s11205-005-8671-9

Biswas-Diener, R., Vittersø, J., \& Diener, E. (2005). Most people are pretty happy, but there is cultural variation: The Inughuit, the Amish, and the Maasai. Journal of Happiness Studies: An Interdisciplinary Periodical on Subjective Well-Being, 6(3), 205-226. https://doi.org/10.1007/s10902-005-5683-8

Diener, E. (1998). Editorial. Journal of Personality and Social Psychology, 74 (1), 5-6. https://doi.org/10.1037/h0092824

Diener, E., \& Clifton, D. (2002). Life satisfaction and religiosity in broad probability samples. Psychological Inquiry, 13(3), 206-209.

Diener, E., Diener, C., Choi, H., \& Oishi, S. (2018). Revisiting “Most People Are Happy” - And discovering when they are not. Perspectives on Psychological Science, 13(2), 166-170. https://doi.org/10.1177/1745691618765111

Diener, E., \& Fujita, F. (1995). Resources, personal strivings, and subjective well-being: a nomothetic and idiographic approach. Journal of Personality and Social Psychology, 68(5), 926-935. https://doi.org/10.1037/0022-3514.68.5.926

Diener, E., Horwitz, J., \& Emmons, R. A. (1985). Happiness of the very wealthy. Social Indicators Research, 16(3), 263-274. https://doi.org/10.1007/BF00415126

Diener, E., \& Lucas, R. (2000). Explaining differences in societal levels of happiness: Relative standards, need fulfillment, culture, and evaluation theory. Journal of Happiness Studies: An Interdisciplinary Periodical on Subjective Well-Being, 1(1), 41-78. https://doi.org/10.1023/A:1010076127199

Diener, E., Ng, W., Harter, J., \& Arora, R. (2010). Wealth and happiness across the world: Material prosperity predicts life evaluation, whereas psychosocial prosperity predicts positive feeling. Journal of Personality and Social Psychology, 99(1), 52-61. https://doi.org/10.1037/a0018066

Diener, E., Ng, W., \& Tov, W. (2009). Balance in life and declining marginal utility of diverse resources. Applied Research in Quality of Life, 3(4), 277-291. https://doi.org/10.1007/s11482-009-9062-1

Diener, E., \& Oishi, S. (2000). Money and happiness: Income and subjective well-being across nations. In E. Diener \& E. M. Suh (Eds.), Culture and subjective well-being (pp. 185-218). Cambridge, MA: MIT Press.

Diener, E., Sandvik, E., Seidlitz, L., \& Diener, M. (1993). The relationship between income and subjective well-being: Relative or absolute?. Social Indicators Research, 28(3), 195-223. https://doi.org/10.1007/BF01079018

Diener, E., Tay, L., \& Oishi, S. (2013). Rising Income and the Subjective Well-Being of Nations. Journal of Personality E Social Psychology, 104(2), 267-276. https://doi.org/10.1037/a0030487 
Diener, E., Tay, L., \& Myers, D. G. (2011). The religion paradox: If religion makes people happy, why are so many dropping out? Journal of Personality and Social Psychology, 101(6), 1278-1290. https://doi.org/10.1037/a0024402

Eid, M., \& Diener, E. (2004). Global judgments of subjective well-being: Situational variability and longterm stability. Social Indicators Research, 65(3), 245-277. https://doi.org/10.1023/B:SOCI.0000003801.89195.bc

Geerling, D. M., \& Diener, E. (2018). Effect size strengths in subjective well-being research. Applied Research in Quality of Life, 1-19. https://doi.org/10.1007/s11482-018-9670-8

Gohm, C. L., Oishi, S., Darlington, J., \& Diener, E. (1998). Culture, parental conflict, parental marital status, and the subjective well-being of young adults. Journal of Marriage and the Family, 60(2), 319334. https://doi.org/10.2307/353851

Heintzelman, S. J., Kushlev, K., Lutes, L. D., Wirtz, D., Kanippayoor, J. M., Leitner, D., ... \& Diener, E. (2020). ENHANCE: Evidence for the efficacy of a comprehensive intervention program to promote subjective well-being. Journal of Experimental Psychology: Applied, 26(2), 360-383. https://doi.org/10.1037/xap0000254

Jebb, A. T., Tay, L., Diener, E., \& Oishi, S. (2018). Happiness, income satiation and turning points around the world. Nature Human Behavior, 2, 33-38. https://doi.org/10.1038/s41562-017-0277-0

Joseph, D. L., Chan, M. Y., Heintzelman, S. J., Tay, L., Diener, E., \& Scotney, V. S. (2020). The manipulation of affect: A meta-analysis of affect induction procedures. Psychological Bulletin,146(4), 355-375. https://doi.org/10.1037/bul0000224

Lucas, R. E., Diener, E., \& Suh, E. (1996). Discriminant validity of well-being measures. Journal of Personality and Social Psychology, 71(3), 616-628. https://doi.org/10.1037/0022-3514.71.3.616

Oishi, S., Diener, E., Lucas, R. E., \& Suh, E. (1999). Cross-cultural variations in predictors of life satisfaction: Perspectives from needs and values. Personality and Social Psychology Bulletin, 25(8), 980990. https://doi.org/10.1177/01461672992511006

Oishi, S., Schimmack, U., \& Diener, E. (2012). Progressive Taxation and the subjective well-being of nations. Psychological Science, 23(1), 86-92. https://doi.org/10.1177/0956797611420882

Scollon, C. N., Diener, E., Oishi, S, \& Biswas-Diener, R. (2004). Emotions across cultures and methods. Journal of Cross-Cultural Psychology, 35(3), 304-326. https://doi.org/10.1177/0022022104264124

Suh, E., Diener, E., Oishi, S., \& Triandis, H. C. (1998). The shifting basis of life satisfaction judgments across cultures: Emotions versus norms. Journal of Personality and Social Psychology, 74(2), 482-493. https://doi.org/10.1037/0022-3514.74.2.482

Tay, L., Morrison, M., \& Diener (2014). Living among the affluent: Boon or bane? Psychological Science, 25(6), 1235-1241. https://doi.org/10.1177/0956797614525786

Wirtz, D., Kruger, J., Scollon, C. N., \& Diener, E. (2003). What to do on spring break? The role of predicted, online, and remembered experience in future choice. Psychological Science, 14(5), 520-524. https://doi.org/10.1111/1467-9280.03455 